\title{
The Implementation of Reinforcement Skill in Teaching English in The Pandemic Situation
}

\author{
Komang Diah Kusuma Werdi ${ }^{1}$ \\ Universitas Pendidikan Ganesha, Indonesia \\ diahkusumawerdi@gmail.com \\ Ni Made Ratminingsih ${ }^{2}$ \\ Universitas Pendidikan Ganesha, Indonesia \\ made.ratminingsih@undiksha.ac.id \\ Putu Eka Dambayana ${ }^{3}$ \\ Universitas Pendidikan Ganesha, Indonesia \\ ekadambayana@gmail.com
}

\begin{abstract}
This study aimed to identify the types of reinforcement skills and investigate the implementation of reinforcement skills used during the online learning process at SMP Laboratorium Undiksha Singaraja. This study used a qualitative descriptive method as the research design. This study also used an English teacher as the research subject. In collecting data, this study used three methods, namely; observation, interview, and questionnaires. This research was conducted online due to the COVID-19 pandemic. Through the data obtained, this study found the results of the type of reinforcement and the implementation used by teachers during online learning. There are four types of reinforcement used by the teachers, such as; (1) positive verbal reinforcement in the form of praise and partial reinforcement, (2) positive non-verbal reinforcement in the form of gestures, (3) negative verbal reinforcement in the form of enforceable statements, questions, calling out the students' names, and (4) negative nonverbal reinforcement in the form of facial expressions and record the students' misbehavior. In addition, the reinforcement implementation was relevant to the theories suggested by experts by following the five principles in giving reinforcement. Further study is needed to get a deeper understanding toward the implementation of reinforcement in EFL classroom.
\end{abstract}

Keywords: Implementation, Reinforcement Skills, Teaching English, Pandemic

\section{INTRODUCTION}

In the world of education, teachers have a very important role in motivating the students' learning process. Teacher professionalism strongly supports the learning process in the classroom. One way that teachers use to motivate students is by implementing reinforcement skills for students every time they teach in class. In general, to motivate students, the teacher will provide reinforcement in the form of praise and reward. However, in 2019, Indonesia experienced an education crisis caused by The Coronavirus Disease-19 (COVID-19). Purwanto et al (2020) state that the COVID-19 pandemic is the 
foremost health crisis in the world. Many countries have decided to close schools and universities.

The spread of the Covid-19 which initially had a major impact on the slowdown in the world economy, is now also being felt by the world of education. Therefore, many countries, including Indonesia, have stopped all educational activities, so that the government and related agencies must present an alternative education process for students who cannot carry out the educational process in schools. Currently in Indonesia, several campuses and schools have started implementing online teaching and learning processes. Social distancing is implemented to break the chain of transmission of COVID-19. The Covid-19 also has a serious impact on the world of education, both in Indonesia and globally.

In that situation, many students feel less appreciation from the teachers and which can affect the online learning process. Many students feel that their efforts and positive behavior are less appreciated. It makes the students not encouraged to give positive responses towards the stimulus from the teacher (Wibowo, 2015). Lacking support from the teacher becomes one of the reasons for the students' feel less appreciation (Calista et al., 2019). Hasibuan \& Moeldjiono (2008) state that students need reinforcement in learning because reinforcement is an award that can lead to encouragement and enthusiasm in learning, but the implementation of reinforcement in the learning process at Junior High School is relatively low (Wibowo, 2015). In addition, students need teachers to provide positive reinforcement that can support students to learn English simply and effectively.

Giving reinforcement is one of the basic teaching skills that a teacher should have (Yatim, 2016). In general, reinforcement is a stimulus to increase the students' probability to do the desired behavior, the main point of providing reinforcement is the enhancement of students' response towards the repetition of that behavior. According to Padmadewi et al (2019), reinforcement is a response given to a behavior that can increase the likelihood of repeating that behavior. The purpose of giving reinforcement is to support and enhance students to be more active in the learning process. By designing the environment properly, the students can be enthusiastic about learning. Thus, the only way to support the students to learn and keep on task is the consistency of making positive changes in the external environment through reinforcement (Weeite, 2015). Padmadewi et al (2019) state that the effective use of reinforcement has to consider five principles such as; providing warm and enthusiast principal, giving meaningful positive verbal reinforcement, avoiding negative response, giving reinforcement to individuals and groups of students, and providing variations of reinforcement.

According to Padmadewi et al (2019), reinforcements are divided into two types, namely verbal reinforcement, and non-verbal reinforcement. Verbal reinforcement is usually shown by using praise, awards, agreements, etc. On another side, on-verbal reinforcement is usually indicated by body gestures. This statement is complemented by Damayanti (2018) which shows that the implementation of the reinforcement skill component includes: verbal reinforcement in the form of praise to students to support students in the form of words and sentences, and non-verbal reinforcement in the form of smiles and movements, approaching students by interacting with students, fun activities in the form of chants or songs as well as symbols and objects. In addition, the 
implementation of providing reinforcement is applied to certain individuals or groups, besides that the implementation of reinforcement is carried out immediately and also provides variations in providing reinforcement.

Wahyuni (2016) believes that reinforcement can be interpreted as a way to encourage students to actively participate in learning activities. Reinforcement gives pride to students who receive it. Students will be happy when the teacher provides reinforcement. The positive reinforcement supports the students to persist in learning activities, so, that the reinforcements will be remembered and felt during the activity. Arista et al (2018) explain that there are five ways to implement reinforcement by giving warm and enthusiastic reinforcement, avoiding the positive meaning, principles of meaningfulness, providing individual or group reinforcement, and the last is with the variation of reinforcement. Reinforcement strategies should be effective to use in the classroom, it is not only taught at school but also from themselves, parents can also cultivate the motivation of learning toward their children, but the motivation that come from their own desire is the best motivation. Besides that, Hafidah (2015) showed an increase in the use of reinforcement skill each cycle. In the first cycle improved implementation of reinforcement skill, they have conducted an average of the percentage of $45.74 \%$ and increased in the second cycle with the percentage of $66.77 \%$ with an increase of $21.03 \%$ and increase students' learning motivation of the first cycle with an average percentage of $50.4 \%$ increase in the second cycle with the percentage of $68.25 \%$ with an increase of $17.85 \%$. So from this research, the researcher stated the implementation of reinforcement skill to the students can increase students' motivation.

To achieve this, teachers and students must support each other and play their roles well in the learning and teaching process. According to Purnamasari et al (2018), the effectiveness of using reinforcement is determined by how it is delivered by the teacher and perceived by the students. It means that the teacher should have clear goals in giving reinforcement for the students. Sholikhah et al (2017) add that a teacher should have good skills in providing reinforcement, which reveals that the presence of reinforcement can make the students feel appreciated and proud of their efforts. Preliminary observations were conducted in January, 2021, at the SMP Laboratorium Undiksha Singaraja, using a zoom meeting platform and attended by approximately 45 students from seventh-grade students, and an English teacher. It was found that Reinforcement skills could not be fully implemented considering that the learning process was still being carried out online. In online learning using a zoom meeting platform, the teacher tends to use positive reinforcement in the form of praising, such as; good, good job, excellent, well done, etc. besides giving rewards in the form of additional scores for students who answered the questions correctly. This situation resulted in the teacher rarely providing nonverbal reinforcement, such as gestures like nodding, smiling, thumbs up, approach or touch.

SMP Laboratorium Undiksha Singaraja was chosen as the setting of the research since it has complete facilities and students thoroughly participate in online learning so that the results of this study can be used as a reference for English teachers in implementing reinforcement skills or knowing the types of reinforcement, so that if there are deficiencies in implementing all types of reinforcement that can be used as a reflection for the teacher to be studied. Based on this description, the researcher was interested in conducting research 
on the process of implementing reinforcement skills in the online learning and teaching process at SMP Laboratorium Undiksha Singaraja in the pandemic of COVID-19. Based on the background of the research there were two research questions formulated for this study. The research questions were as follows. (1) What are the types of reinforcement skill implemented in online learning process in SMP Laboratorium Undiksha Singaraja. (2) How is the implementation of reinforcement in online learning process in SMP Laboratorium Undiksha Singaraja. Research objectives were as follows. (1) To describe the type of reinforcement skill used in the online learning process at SMP Laboratorium Undiksha Singaraja. (2) To investigate how the teacher implements the reinforcement in the online learning process at SMP Laboratorium Undiksha Singaraja.

\section{METHOD}

This study aimed to find out and analyze the types of reinforcement that are given by the teacher and how the teacher implements the reinforcement skill when teaching English in the context of online learning during the COVID-19 pandemic. Therefore, descriptive qualitative study was chosen as the design of this study. Qualitative study is defined as a study that aims to understand the meaning of individual or group as well as exploring the social or human phenomena (Creswell, 2014). Thus, descriptive qualitative design was used to qualitatively describe a social phenomenon. Descriptive research is also defined as a research design that is used to systematically and accurately describe and examine an existing phenomenon (Williams, 2007; Atmowardoyo, 2018). Moreover, the data in descriptive research are usually collected through questionnaires, interviews, and observations. Considering its characteristics, descriptive qualitative research is considered appropriate as the design of the study. This study was conducted at SMP Laboratorium Undiksha Singaraja that is located in Jalan Jatayu No.10, Kaliuntu, Buleleng Regency, Bali. English is taught as a compulsory subject. There were two meetings in a week with 80 minutes of time allocation for each meeting. The setting was chosen with the consideration of the COVID-19 pandemic situation whereas the setting is close from the researcher's home. The subject of this study was an English teacher at SMP Laboratorium Undiksha Singaraja who teaches the seventh grade students that are grouped to three classes, including VII-1, VII-2, and VII-3 with the total of 55 students.

The objects of this study were the types of reinforcement and the implementation of reinforcement skill in teaching English in SMP Laboratorium Undiksha Singaraja. This study has two variables, such as reinforcement and its implementation. Theoretically, reinforcement is a response given to a behavior that can increase the likelihood of repeating that behavior (Padmadewi et al., 2019). There are two types of reinforcement which includes verbal and nonverbal reinforcement (Usman, 2005;Sari \& Paradina, 2018). Furthermore, it is suggested that the verbal and non-verbal reinforcement can be categorized into positive and negative reinforcement. Therefore, operationally, the types of reinforcement discussed in this study are the positive and negative verbal and non-verbal reinforcement that are used by the teacher at SMP Laboratorium Undiksha Singaraja during the online learning process in the COVID-19 pandemic situation. 
Theoretically, reinforcement implementation is the process of implementing the response given to a behavior that can increase the likelihood of repeating that behavior. Operationally, the reinforcement implementation discusses in this study is the process of implementing reinforcement that is conducted by the teacher at SMP Laboratorium Undiksha Singaraja during the online learning process in the COVID-19 pandemic situation. A set of method and instruments of data collection was carried out in order to collect the data for the study. The method and instrument of data collection can be seen on Table 1.

Table 1. Method and Instruments of Data Collection

\begin{tabular}{|c|c|c|c|}
\hline Research Question & Data & Method & Instrument \\
\hline $\begin{array}{l}\text { What are the types of } \\
\text { reinforcement skill } \\
\text { implemented in online } \\
\text { learning process in } \\
\text { SMP Laboratorium } \\
\text { Undiksha Singaraja. }\end{array}$ & $\begin{array}{l}\text { The types of } \\
\text { reinforcement used } \\
\text { during the online } \\
\text { learning process }\end{array}$ & Questionnaire & $\begin{array}{l}\text { Closed-ended } \\
\text { questionnaire }\end{array}$ \\
\hline \multirow{2}{*}{$\begin{array}{l}\text { How is the } \\
\text { implementation of } \\
\text { reinforcement in online } \\
\text { learning process in } \\
\text { SMP Laboratorium } \\
\text { Undiksha Singaraja. }\end{array}$} & $\begin{array}{l}\text { The implementation of } \\
\text { reinforcement in online } \\
\text { learning process }\end{array}$ & Observation & $\begin{array}{c}\text { Observation } \\
\text { sheet }\end{array}$ \\
\hline & $\begin{array}{l}\text { Confirmation and detail } \\
\text { about the } \\
\text { implementation of } \\
\text { reinforcement }\end{array}$ & Interview & $\begin{array}{c}\text { Interview } \\
\text { guide } \\
\text { Audio recorder }\end{array}$ \\
\hline
\end{tabular}

Validity is the test used to know the appropriateness of the instruments (Fraenkel \& Wallen, 2009). According to Fraenkel \& Wallen (2009) validity test is also used to measure the degree of accurateness of the test before collecting the data. Therefore, it needs to be examined. Content validity was conducted to validate the instruments in which it is a kind of measurement to measure the validity of the content whether the content is appropriate or not. Two experts were required in order to check the appropriateness of the questions. The instruments passed two steps. First, the two experts reviewed the blueprint. Then, some suggestions or revisions were toward the questions on the blueprint. Second, all the experts' suggestions or revision were compared and analyzed by using Gregory's formula. This formula was used to determine the content validity. Cross tabulation table was used to put the examination result between both experts. The analysis method used in this study was adapted from theory suggested by Creswell's qualitative data model. It divides the data analysis technique into four steps, such as organizing and preparing the data, reading all the data, representing the data in qualitative narrations, and interpreting the data. The four steps of data analysis model of Creswell (2009) can be seen in the Figure 3.1 
The Art of Teaching English as a Foreign Language, Vol 2. No.2 2021

p-ISSN : 2656-8942, e-ISSN : 2684-8546

DOI: $10.36663 /$ tatefl.v2i1.139

Figure 1. Four Steps of Data Analysis Model

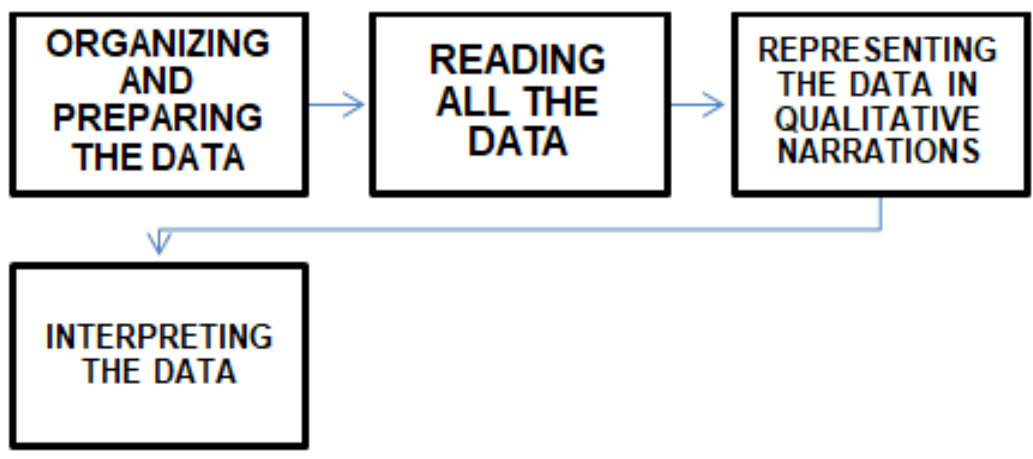

The first step, the researcher compiled and prepared the researcher data by copying the questionnaire and interview list, sorting the material optically, typing a list of questions, and also sorting and compiling different data on each information source. Second, the researcher read all the data and provides a general understanding of the information and the opportunity to reflect on the overall meaning. Third, the researcher presented the data in a qualitative narrative. At this step the researcher discussed the chronology of events and several related topics. Finally, the researcher interpreted the data in the form of the researchers' understanding and interpretation obtained from personal culture, history, and experiences. Also, it could be the meaning that comes from a comparison between literature and theory.

In addition, triangulation is defined as an approach data analysis that synthesizes data from multiple source (Bachri, 2010). Triangulation is a technique of checking the validity of data by utilizing something from outside the data itself, for checking purposes or as a comparison of the data. In this study, researcher used Triangulation Method, Triangulation method is an effort to check the validity of the data, or to check the validity of research findings. Triangulation methods can be done by using more than one data collection technique to obtain the same data. Therefore, this study used 3 data collection techniques, including observation, interview, and questionnaire. The triangulation process can be seen on Figure 2.

Figure 2. Triangulation Process

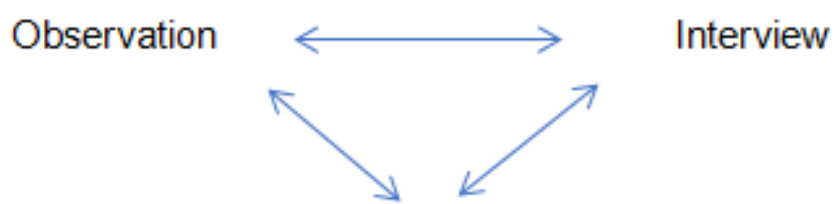

Questionnaire 


\section{FINDINGS \& DISCUSSIONS}

The findings of the questionnaire indicated several things that are worth to be discussed further related to how the seventh-grade English teacher at SMP Laboratorium Undiksha Singaraja implemented the types of reinforcement in the online learning process. The findings of this research indicated that from the four dimensions of types of reinforcement suggested by Usman (2005) and Sari and Paradina (2018), the seventh grade English teacher at SMP Laboratorium Undiksha Singaraja almost has implemented all of types of reinforcement. Based on the results of the questionnaire, it can be seen that the teacher delivered the positive verbal reinforcement. The teacher praised the students by saying praises like "yes, great, right, good, and so on" when they do their assignment correctly or when the students can answer questions correctly. Not only that, the teacher also given compliment for the students when they submit their works on time. Further, the teacher given partial reinforcement to emphasize the appreciation to the students when they answer a question incorrectly, and also to express and encourage the students more by saying "yes your answer was good, but it still needs to be refined". The teacher also often shows positive nonverbal reinforcement in the form of gestures like thumbs up, applause, and bright smile after the students answer questions correctly or actively participating in the class and when students have done a good job in presenting their work. In the case of negative reinforcement, the teacher often gave negative verbal reinforcement in the form of call out the students' name, enforceable statement, and question. When the students do not pay attention to the class, the teacher call out the students' name, moreover the teacher warns the students that they need to be calm in order for me to begin the class and tell the students that the class can only be ended when they have done the task. Furthermore, when the students are busy with their own activity, the teacher asked them to pay more attention to the class, and spontaneously ask students about the materials that he was explaining. The teacher also often shows negative non-verbal reinforcement in the form of facial expression by showing frowned face to the students when they do not pay attention to the class, and then sometimes record the students' misbehavior by make notes of those who are noisy during the lesson and put minus remark for being noisy and not following the lesson on the students name on the presence list. Other the negative non-verbal reinforcement in the form of gestures, and waiting, were never conducted by the teacher.

Therefore, based on the findings of this research, this section will discuss further about the types of reinforcement was implemented by the teacher in accordance to the principles of the types of reinforcement suggested by Usman (2005) and Sari and Paradina (2018). In the positive verbal reinforcement, the teacher gave praise and partial reinforcement to appreciate the students' good work, good effort in the learning process, good punctuality in collecting homework or project, and also encourage the students when they got bad grades for their assignment and tests. In the positive non-verbal reinforcement, the teacher gave a positive gesture by showing his thumbs up and clapping his hands when the students did a great job during the learning process, and also give student bright smile when they can answer correctly or actively participating in the class. In the negative verbal reinforcement, the teacher called out the students' names, give an enforceable statement by warn or tell the students that they need to be calm in order to begin the class and the class can only be ended when they have done the task and also ask them to pay more attention to the 
class and gave them spontaneous questions in order to make them focus on the learning process. Finally, for the negative non-verbal reinforcement, the teacher gave negative facial expression in which he showed a frowned face when the students do not pay attention to the class, the teacher also makes note of those who are noisy during the lesson, and put minus remark for being noisy and not following the lesson on the students' name on the presence list. The types that the teacher did not implement were negative non-verbal reinforcement gestures, and waiting. Based on this discussion, it can be seen that the results of this research were in line with the ones found by Usman (2005) and Sari and Paradina (2018). The research found that there were 4 types of reinforcement, namely verbal and non-verbal reinforcement. Sari and Paradina (2018) further suggest that the verbal and non-verbal reinforcement can be categorized into positive and negative reinforcement. So that the four types of reinforcement are positive verbal reinforcement, positive non-verbal reinforcement, negative verbal reinforcement, and negative non-verbal reinforcement. Besides the four types of reinforcement suggested above, Hasibuan and Moeldjiono (2008) also suggested that the types of reinforcement that teachers provide to students should be appropriate increasing student attention to learning, increasing motivation to learn, and increasing learning activities and fostering productive behavior which has been highlighted throughout the findings. The findings of this research indicated that the teacher almost has implemented all the types of reinforcement to the students. When the students did a good work, or show good effort in the learning process, the teacher immediately responded with positive verbal and non-verbal reinforcement. The same goes when the students show misbehavior and undesirable attitude, the teacher came up with negative verbal and non-verbal reinforcement.

The findings of the observation and the interview indicated several things that are worth to be discussed further related to how the seventh-grade English teacher at SMP Laboratorium Undiksha Singaraja implemented reinforcement in the online learning process. Therefore, based on the findings of this research, this section will discuss further about the way the reinforcement was implemented by the teacher in accordance to the principles of implementing reinforcement suggested by Usman (2005) and Arista et al (2018), along with the situation when the reinforcement was implemented by the teacher in accordance to the theory suggested by Djamarah (2005) and Usman (2005). Based on the results of the observation, it can be seen that the teacher delivered the positive verbal reinforcement in a warm attitude. This is in line with one of the five principles of the theory suggested by Usman (2005) and Arista et al (2018) in which teachers need to provide warmth and enthusiasm in giving the positive reinforcement. The warmth and enthusiasm principle explains that the teachers need to make sure that the students can feel the sincerity and enthusiasm of the teachers in giving positive verbal and non-verbal reinforcement to the students. When the teachers praise the students for their hard work in a cheerful, enthusiast, and sincere manner, the students will feel more appreciated and welcomed. As the results, a comfortable and warm classroom atmosphere can be built and the students can be better reinforced positively so that they will repeat the desirable actions and behavior in the future. The teacher praised the students by saying praises like good job, well done, very good, good answer, good attempt, good, great idea, OK, correct, excellent, very well, wonderful, and great. Not only that, the teacher also called the students' names right after the 
praises in order to make them feel more appreciated and encouraged them to repeat the desirable behavior of the good work. Further, to emphasize the appreciation that he wanted to express and encourage the students more, the teacher also often show positive gesture like thumbs up and applause after praising the students. Therefore, it can be seen that the teacher has followed a good implementation of positive reinforcement. Besides warmth and enthusiasm, the findings of the research showed that the teacher expressed the meaningfulness of his reinforcement by giving further explanation of why the reinforcement was given. This is in line with the second principle of the theory suggested by Usman (2005) and Arista et al (2018) in which teachers need to provide meaningfulness in giving reinforcement. By meaningful, the reinforcement needs to show the value of what the students have achieved to make them receive such compliments or warns. A meaningful reinforcement will make the students understand on what extent they are being reinforced and the reasons why the teacher reinforces them. By providing a meaningful reinforcement, the teacher will let the students know that they deserve the reinforcement.

For instance, when giving positive verbal reinforcement in the form praises, the teacher did not just say good job, well done and so on. Instead, the teacher also provided information of what was good and what was being praised. The example is when the teacher praised one of the students named Evali after she gave a good answer about a question. The teacher praised her by saying "Very Good Explanation. That's great, Evali." It can be seen that the teacher tried to make the reinforcement becomes more meaningful by pointing at the thing that was being reinforced so that the students knew that they really did have done a great job. In the case of negative reinforcement, the practice of meaningfulness by the teacher can be seen on the way the teacher gave negative verbal reinforcement in the form of question. When the teacher addressed some students who did not make the assignment, the teacher went and said "Why don't you make the exercise, Gusti Ayu Gita, Masrya and Riki Candra? Do you have any reasons for that? There is no reason?" It can be seen that the teacher did not randomly calling the students out and bombarded them with questions without a clear reason. The teacher clearly makes it meaningful by stating the reason why the students need to be questioned and negatively reinforced since they did not fulfill their responsibilities. This way, the students would be aware of the fact that they deserved to be negatively reinforced. The third principle is avoiding the use of negative response. Negative response here refers to the teacher's response in reinforcing the students in which the teacher blames students for their inability to answer certain questions or in certain misbehavior. Wulandari (2019) suggests that instead of blaming and shouting at the students for not being able to answer certain questions, it is better for the students to switch the question or move to other students. This is important to be conducted in order to avoid making students feel demotivated and stop to develop themselves. In order to overcome the barriers, students have to build motivation inside their mind whether it is intrinsic or extrinsic motivation (Schunk, 2008). Therefore, avoiding the use of negative response is important to be considered in implementing reinforcement.

When being compared to how the teacher at SMP Laboratorium Undiksha Singaraja implemented reinforcement in his online learning process, it can be seen that there are some implementations that has reflected the 
principles. Take for instance the implementation of partial reinforcement which was always implemented by the teacher. Partial reinforcement as suggested by Sari and Paradina (2018) is given when the students give answer that is only partial true. Under these circumstances, the teacher may not directly blame the students. In the implementation, the teacher did not directly blame the students since he wanted to appreciate the students' effort in trying to answer or do certain questions or tasks. The teacher gave the students chance to answer questions or participate in the learning process and then gave them partial reinforcement as an appreciation. In the practice, the findings showed that the teacher did not hurriedly negatively comment the students' performance. Instead, he firstly gave praises then followed by certain phrases that contained suggestions for improvement or corrections for the students' mistakes. The teacher also mentioned the students' names following the partial reinforcement in order to make the reinforcement felt more personal to the students. The example of the reinforcement was "Okay. Good attempt. But you should say advertisement."

The praises were not only directed to individual students since sometimes they were also given to a group of students. Take for instance, the reading dialogue task. The reading dialogue task was done by at least two students and therefore the teacher praised both of the students when they could perform well. When some students responded together to the teacher's question, the teacher also gave praises in group by saying very good, great, and correct. The results also suggest that the teacher gave reinforcement both to individuals and groups. This is in line with the theory suggested book, Usman (2005) that reinforcement should be given both to individuals and group of students. When being given individually, the subject of the reinforcement needs to be clear. This can be done by mentioning the name of the students so that it can be clear to whom the reinforcement is intended to. Besides making it clear, this principle also makes sure that the students can feel the sense of being appreciated as the teacher acknowledged their good work in learning. Regarding the findings of this research, it can be seen that the teacher always put the names of the students in the phrases of his reinforcement, such as the positive verbal reinforcement in the form of praises or the negative verbal reinforcement in the form of questions. Further, the teacher also implemented negative verbal reinforcement in the form of calling out the students' names, which certainly make the target of the reinforcement clear, following the guide of this principle. On the other hand, when being given to a group of students, the teacher can give the students certain reward to appreciate their good work. For instance, the teacher can give rewards in forms of token or activity reinforcement. When being related to the findings of this research, it can be seen that the teacher did not conduct this principle for the reinforcement given to groups of students. This happened not because the teacher did not want to but rather because he could not. It was because the learning process was done online due to the COVID-19 pandemic and therefore physical contact in the form of token or activity reinforcement was not possible. Instead, to make up for this situation, the teacher gave group of students praises when they were able to work well and negative verbal reinforcement when they misbehaved.

Finally, the findings also indicate that the teacher has used several ways to reinforce the students through the implementation of positive and negative reinforcement. This implementation is in line with the last principle that is 
proposed by Usman (2005) and Arista et al (2018) which is variation. It is suggested that in giving reinforcement it is important for the teacher to make sure that the students will not feel bored for receiving the same forms of reinforcement over and over again. Moreover, the same forms of reinforcement will make it seem to be less meaningful to the students and therefore will lessen its benefits in motivating the students. Therefore, they suggest teacher needs to reinforce the students in various ways. The findings of this research indicated that from four dimensions of reinforcement suggested by Sari and Paradina, (2018), the seventh grade English teacher at SMP Laboratorium Undiksha Singaraja has implemented all of them with some types for each dimension. In the positive verbal reinforcement, the teacher gave praises and partial reinforcement to appreciate the students' good work. In the positive non-verbal reinforcement, the teacher gave positive gesture by showing his thumbs up and clapping his hands when the students did a great job during the learning process. In the negative verbal reinforcement, the teacher called out the students' names and gave them spontaneous questions in order to make them focus in the learning process. Finally, for the negative non-verbal reinforcement, the teacher gave negative facial expression in which he showed sullen expression when the students did not want to pay attention to the class. The types that the teacher did not implement was enforceable statement, negative non-verbal gestures, waiting, and recording the students' misbehavior.

Based on this discussion, it can be seen that the results of this research was in line with the ones found by Arista et al (2018). The research found that there were 5 ways of reinforcement implementation. First, reinforcement was given with warmth and enthusiasm; second, negative reinforcement was avoided; third, reinforcement was emphasized on meaningfulness; fourth, reinforcement was given to both group and individual; and fifth, reinforcement was given with variation in types and purposes. Besides the five principles suggested above, Usman (2005) also suggests that teacher needs to pay attention on the immediacy of the reinforcement given. Immediacy in giving reinforcement is crucial since once the reinforcement was delayed then it will not be as effective and impactful as it should be. Therefore, it is suggested that reinforcement needs to be given as soon as possible when the students perform the intended behavior. Which has been highlighted throughout the findings. The findings of this research indicated that the teacher has always immediately gave the reinforcement to the students. When the students did a great job or show an effort in the learning process, the teacher immediately responded with positive verbal and non-verbal reinforcement. The same goes when the students show misbehavior and undesirable attitude, the teacher came up with negative verbal and non-verbal reinforcement. The results of the study indicated that the teacher has implemented reinforcement in accordance to the theory suggested by Sari (2019). The teacher conducted reinforcement in the forms of (1) positive verbal reinforcement, (2) positive non-verbal reinforcement, (3) negative verbal reinforcement, and (4) negative non-verbal reinforcement. Further, the findings also demonstrated that the teacher showed a good practice of reinforcement as he conducted it by following the five principles of reinforcement practice suggested by Usman (2005) and Arista et al (2018). However, the principles suggest that the teacher needs to include variations in practicing reinforcement. Even though the results indicated that the teacher has conducted various kinds of reinforcement in the online learning, there are some kinds that were not being 
implemented while they could actually be done. Thus, the results of this study indicated that the teacher has done a good job in implementing reinforcement in the online learning process. However, there is still room for improvement and better implementation.

\section{CONCLUSIONS}

According to finding and discussion, there were several conclusions that could be made. First, there were four types of reinforcement that teacher used in the online learning. They were (1) positive verbal reinforcement in the forms of praises and partial reinforcement, (2) positive non-verbal reinforcement in the form of gestures, (3) negative verbal reinforcement in the forms of enforceable statement, questions, and by calling out the students' names, and (4) negative non-verbal reinforcement in the form of facial expression and record the students' misbehavior. Second, the reinforcement implementation was relevant to the theories suggested by experts by following the five principles in giving reinforcement.

\section{REFERENCES}

Arista, D., Artini, L. ., \& Ratminingsih, N. M. (2018). The Types of Reinforcement Strategies Used by The Teacher in Motivating EFL Students at KG B Class in Bali Kiddy School. JPAI (Journal of Psychology and Instruction), 2(1), 915.

Atmowardoyo, H. (2018). Research Methods in TEFL Studies: Descriptive Research, Case Study, Error Analysis, and R\&D. Journal of Language Teaching and Research, 9(1), 197-204. https://doi.org/DOl: http://dx.doi.org/10.17507/jltr.0901.25.

Bachri, B. S. (2010). Meyakinkan Validitas Data Melalui Triangulasi Pada Pendidikan Kualitatif. Jurnal Teknologi Pendidikan, 4(1), 46-62.

Calista, V., Kurniah, N., \& Ardina, M. (2019). Hubungan Reinforcement terhadap Disiplin Anak Usia Dini di Paud Pembina 1 Kota Bengkulu. Jurnal IImiah Potensia, 4(1), 13-17.

Creswell, J. W. (2009). Research Design: Qualitative, quantitative, and mixed methods approaches (3rd editio). Sage Publications; International Educational and Professional Publisher.

Creswell, J. W. (2014). Research Design Qualitative, Quantitative, and Mixed Methods Approaches (4th editio). Sage Publications; International Educational and Professional Publisher.

Damayanti, I. (2018). Penerapan Kompenen Reinforcement Skill Pada Pembelajaran Tematik Kelas III C MIN 1 Yogyakarta. Universitas Islam Negeri Sunan Kalijaga.

Djamarah, S. B. (2005). Guru dan anak didik dalam interaksi anak didik. Rineka Cipta.

Fraenkel, J. R., \& Wallen, N. E. (2009). How to Design and Evaluate Research in Education (Seventh Ed). McGraw-Hill Hgher Education, Inc.

Hafidah, M. N. (2015). Implementasi Metode Reinforcement untuk Meningkatkan Motivasi Belajar Tunagrahita Sekolah Menengah Pertama Luar Biasa Sekolah Luar Biasa Pembina Tingkat Nasional Malang. Universitas Islam Negeri Maulana Malik Ibrahim.

Hasibuan, \& Moeldjiono. (2008). Proses Belajar Mengajar. PT. Remaja Rosdakarya. 
Padmadewi, N. N., Artini, L. P., \& Agustini, D. A. (2019). Pengantar Micro Teaching. PT. Raja Grafindo Persada.

Purnamasari, N. M., Marhaeni, A. A., \& Artini, L. P. (2018). Development of Teachers Guide in Using Reinforcement Strategy for TEYL. Jurnal Pendidikan Indonesia Undiksha, 7(1), 21-28.

Purwanto, A., Pramono, R., Asbari, M., Santoso, P. B., Wijayanti, L. M., Choi, C. H., \& Putri, R. S. (2020). Studi Eksploratif Dampak Pandemi COVID-19 Terhadap Proses Pembelajaran Online di Sekolah Dasar. EduPsyCouns: Journal of Education, Psychology and Counseling, 2(1), 1-12. https://ummaspul.e-journal.id/Edupsycouns/article/view/397

Sari, N. W. I., \& Paradina, N. L. P. T. (2018). The Use of Reinforcement in Writing and Speaking Skill for Adult Learners in Mahasaraswati University. Advances in Social Science, Education and Humanities Research (ASSEHR), 26(7), 111-119. https://doi.org/https://doi.org/10.2991/aecon18.2018.24.

Schunk, D. H. (2008). Metacognition, self-regulation, and self-regulated learning: Research recommendations. Educational Psychology Review, 20(4), 463467.

Sholikhah, L. D., Sugiharto, D. Y., \& Tadjri, I. (2017). Model Konseling Kelompok dengan Teknik Penguatan Positif untuk Mereduksi Prokrastinasi Akademik Siswa. Jurnal Bimbingan Konseling, 6(1), 62-67.

Usman, U. (2005). Menjadi Guru Professional. PT Remaja RosdaKarya.

Wahyuni. (2016). Hubungan antara Reinforcement dan Motivasi Belajar Matematika siswa kelas V Sekolah Dasar Segugus II Nanggulan Kulon Progo Prodi PGSD. Basic Education Jurnal Elektronik Mahasiswa, 5(10), 958-969.

Weeite, W. E. (2015). Psychology Applied to Modern Life, Adjustment in the 21st. Cengage Learning.

Wibowo, A. (2015). Reinforcement Application by Subject Teacher and Implications of Guidance and Counseling. Journal of Guidance and Counseling, 5(2), 16-33.

Williams, C. (2007). Research Methods. Journal of Business \& Economic Research, 5(3), 65-72.

Wulandari, D. A. (2019). The student teachers' verbal and non-verbal reinforcement during teaching practice in microteaching class. Sunan Ampel State Islamic University. Published Thesis. 